\title{
Employability Skills of Public University Students: A Mismatch between Importance and Competence
}

\author{
Mohamad Arsyhad Rosdi, Rabeatul Husna Abdull Rahman, Salwa Abdul Patah, \\ Wan Mohd Azam Wan Mohd Yunus, Nurul Labanihuda Abdull Rahman
}

\begin{abstract}
This article is based on a cross-sectional study conducted towards 150 third-year undergraduate students in a local public university. The study was conducted mainly to investigate the students' perceptions of the importance of a set of employability skill and their perceived level of competence at performing these skills. The skills are categorized into five groups, namely: (1) problem-solving and analytic skills; (2) time management skills; (3) creativity, innovation, and change skills; (4) learning skills; and (5) personal strength. Data was collected using questionnaires. The findings revealed a mismatch between the students' perception of the importance of the skills and their level of competency for these skills. In specific, they perceived that this set of employability skills is highly important, however, their level of competency is at a moderate level. This finding signifies the need for the university to embed these skills into the curriculum, as well as to conduct more programmes in order to prepare these future graduates for the job market.
\end{abstract}

Keywords: employability skills, undergraduate students, public university, perceived importance, perceived competence.

\section{INTRODUCTION}

$T_{\text {he competitiveness of the local job market is }}$ ever-increasing as a result of globalization which allows companies to expand their search for talent beyond the boundaries. As a result, our local talents such as fresh graduates from public universities have to compete for jobs not only among themselves but also with other graduates from other public and private universities, as well as against international graduates who are seeking for jobs in our country. Therefore, having the right skills are crucial in order to increase a student's employability success rate $[3,6,12]$.

Revised Manuscript Received on October15, 2019

* Correspondence Author

Mohamad Arsyhad Rosdi, Faculty of Social Sciences and Humanities, Universiti Teknologi Malaysia, Johor Bahru, Malaysia. Email: marsyhadr@gmail.com

Rabeatul Husna Abdull Rahman, Faculty of Social Sciences and Humanities, Universiti Teknologi Malaysia, Johor Bahru, Malaysia. Email: rabeatulhusna@utm.my

Salwa Abdul Patah*, Faculty of Social Sciences and Humanities, Universiti Teknologi Malaysia, Johor Bahru, Malaysia. Email: salwaaf@utm.my

Wan Mohd Azam Wan Mohd Yunus, Faculty of Social Sciences and Humanities, Universiti Teknologi Malaysia, Johor Bahru, Malaysia. Email: wmohdazam@utm.my

Nurul Labanihuda Abdull Rahman, Faculty of Business and Management, Universiti Teknologi MARA, Kedah, Malaysia. Email: labanihuda@gmail.com
Yahya [22] defines employability skills as an overview of a person's character which includes attitudes, behaviour, communication style, problem-solving and decision making. Overtoom [12] on the other hand indicated that employability skills refer to a set of skills which encompasses various aspects such as knowledge, skills, and attitudes that are considered necessary to achieve success at all levels of one's career. Whereas Yorke [23] argued that although employability requires a set of skills, it is insufficient to guarantee employment. Instead, the author suggests that readiness to work is the prerequisite to starting any job. Regardless, Sachs, Rowe and Wilson [16] stated that both factors - readiness and employability skills are important to increase the chances of getting employed.

Among the skills that are considered important to be employable are communication skill, team working skill, problem-solving skill [20], academic skill, self-management skill [22], analyzing, synthesizing, thinking skill [13], being responsible, self-control, social skill, integrity, adaptability and flexibility, cooperativeness, self-motivation [19], and leadership skill [11].

Employability skills such as analytical and problem-solving skill are crucial not only to compete in the labour market but also to meet the country's demands [17]. Employers favour graduates who possess the ability to think critically and creatively in completing their job tasks [15] as they no longer have to explain the tasks in detail [21]. Besides, learning skills is also important as it enables graduates to adapt and change more easily [5]. Graduates are also expected to demonstrate the willingness and the ability to learn in order to succeed in their job search [4].

Nevertheless, past studies have shown that there are various factors that impede Malaysian graduates from getting hired. These factors are - lack of creativity [10], unrealistic salary [18], and lack of soft skills such as creativity and critical thinking skill [2]. Thus, Shafie and Surina [19] suggested that the university, in specific, the lecturers to play a role in preparing the students for employment, such as by ensuring that the students possess the skills that are required by the industries. They also highlight the mismatch between the classroom learning at the university and the employers' actual expectation - which students are unaware of. 
Therefore this study was conducted mainly to investigate the students' perceptions of the importance of a set of employability skill and also their perceived level of competence at performing these skills. The skills are categorized into five groups, namely: (1) problem-solving and analytic skills; (2) time management skills; (3) creativity, innovation, and change skills; (4) learning skills; and (5) personal strength.

\section{METHOD}

This study employed quantitative research methodology using a cross-sectional survey to collect the data. It involved the third-year undergraduate students in one faculty in a public university in Malaysia. In total, the faculty has six programmes of study at bachelor degree level whereby all the third-year students were considered as the population for this study. The programmes of study include Human Resource Development, Accountancy, Psychology, Marketing, Management Technology (Operation), and Management Technology (Innovation). This study only surveyed the third-year students as at the time this study was conducted, the fourth-year students were undergoing internship in the industries and were hard to reach.

Stratified and convenient sampling methods were then administered to select the respondents of this study. Upon obtaining the name list of all third-year students from the office administration, this study then determined the required sample. Based on the recommendation by Krejcie and Morgan [9], the number of acceptable samples required was 160 students. This study used the following formula: $\mathrm{Y}=\mathrm{X}(\mathrm{n}) / \mathrm{N}$ to determine the number of questionnaires to be distributed for each programmes of study. Table I shows the distribution of questionnaires by programmes of study.

Table- I: Distribution of Questionnaires by Programmes of Study

\begin{tabular}{|c|l|c|c|}
\hline No & \multicolumn{1}{|c|}{ Programmes } & Calculation & $\begin{array}{c}\text { No. of } \\
\text { Questionnaires } \\
\text { Distributed }\end{array}$ \\
\hline 1 & $\begin{array}{l}\text { Bachelor Programmes Human } \\
\text { Resource Development }\end{array}$ & $\begin{array}{c}160(52) / \\
251\end{array}$ & 33 \\
\hline 2 & $\begin{array}{l}\text { Bachelor Programmes } \\
\text { Management Technology } \\
\text { (Operation) }\end{array}$ & $\begin{array}{c}160(29) / \\
251\end{array}$ & 18 \\
\hline 3 & $\begin{array}{l}\text { Bachelor Programmes } \\
\text { Management Technology } \\
\text { (Innovation) }\end{array}$ & $\begin{array}{c}160(21) / \\
251\end{array}$ & 13 \\
\hline 4 & $\begin{array}{l}\text { Bachelor Programmes } \\
\text { Management }\end{array}$ & $160(51) /$ & 33 \\
\hline 5 & $\begin{array}{l}\text { Bachelor Programmes } \\
\text { Psychology }\end{array}$ & $160(56) /$ \\
\hline 6 & $\begin{array}{l}\text { Bachelor Programmes } \\
\text { Accountancy }\end{array}$ & $160(42) /$ \\
\hline \multicolumn{2}{|c|}{ Total } & 36 \\
\hline
\end{tabular}

The questionnaire was adapted from Rateau [14] which consisted of 24 items. Apart from the demographic section and the employability skills section, the survey also asked the students to indicate their participation in employability related programmes conducted by their university. As mentioned earlier, the students' employability skills were measured by five dimensions namely problem-solving and analytic skill, time management skill, creativity, innovation, and change skill, learning skill, and personal strength. Likert

scale in the range of 1 to 5 was used to measure both the perceived level of importance and the perceived level of competence, whereby $1=$ not important and $5=$ don't know, and $1=$ no competence and $5=$ don't know, respectively.

The problem-solving and analytic skill dimension consisted of six items such as identifying problems and solving problems. Time management skill dimension is comprised of four items, for instance, setting priorities and allocating time efficiently. Whilst creativity, innovation, and change skill dimension were measured using five items, for example, adapting to situations of change and providing novel solutions to problems. The last two dimensions: learning skill and personal strength skill - sample items; gaining new knowledge from everyday experiences, and responding positively to constructive criticism respectively.

This study also performed a reliability analysis to ensure that the questionnaire has high reliability. Approximately [41] students from a different faculty in the same university were involved in the pilot test. The following Table II presents the Cronbach alpha values for each dimension of employability skills, whereby the result suggests that the questionnaire is reliable for this study.

Out of 160 questionnaires distributed, only 150 were returned and used for analysis (94\% response rate). The data were then analyzed using Statistical Package for Social Sciences (SPSS) whereby descriptive statistical analysis were performed to answer the objectives of this study.

Table- II: Reliability Test Result

\begin{tabular}{|l|c|}
\hline Employability Skill Dimensions & $\begin{array}{c}\text { Cronbach } \\
\text { Alpha }\end{array}$ \\
\hline Problem-solving and analytic & 0.825 \\
\hline Time management & 0.789 \\
\hline Creativity, innovation and change & 0.760 \\
\hline Learning & 0.714 \\
\hline Personal strength & 0.835 \\
\hline
\end{tabular}

\section{RESULT}

\section{A. Demographics}

Majority of the respondents were female (86\%), of Malay ethnic (78\%), 22 years of age (44\%), from the Psychology programme $(22 \%)$, and with CGPA result between the range of 3.50 to $4.00(47 \%)$. Besides, it was also found that 50 percent of the students have participated in various employability related programmes in their university, for example, Career Development Programme, Interview Training Programme, Microsoft Excel Training Programme, and Soft Skills Training Programme.

\section{B. Perceived Importance}

Based on our analysis, it was found that the students perceived that all five dimensions of employability skills were highly important. The result is shown in Table III. The highest mean score was for time management skills followed by problem-solving and analytic skill, learning skill, creativity, innovation and change skill, and personal strength skill. 
Table- III: Level of Importance

\begin{tabular}{|c|l|c|c|c|}
\hline No & $\begin{array}{l}\text { Employability } \\
\text { Skill Dimensions }\end{array}$ & $\begin{array}{l}\text { Total } \\
\text { Mean } \\
\text { Score }\end{array}$ & $\begin{array}{l}\text { Standard } \\
\text { Deviation }\end{array}$ & Level \\
\hline 1 & $\begin{array}{l}\text { Problem-solving and } \\
\text { analytic }\end{array}$ & 3.90 & 0.68 & High \\
\hline 2 & Time management & 3.97 & 0.62 & High \\
\hline 3 & $\begin{array}{l}\text { Creativity, innovation } \\
\text { and change }\end{array}$ & 3.80 & 0.66 & High \\
\hline 4 & Learning & 3.88 & 0.65 & High \\
\hline 5 & Personal strength & 3.77 & 0.71 & High \\
\hline
\end{tabular}

\section{Perceived Competence}

Our study also revealed that the students' perceived competency level for all five dimensions of employability skills were at a moderate level. The result is shown in Table IV. This result implies that the students felt that they are moderately competent in all the skills especially for time management skills, problem-solving and analytic skills and learning skills. They are however less competent in creativity, innovation and change skills as well as in personal strength skills.

Table- IV: Level of Competence

\begin{tabular}{|r|l|l|c|c|}
\hline No & $\begin{array}{l}\text { Employability } \\
\text { Skill Dimensions }\end{array}$ & $\begin{array}{l}\text { Total } \\
\text { Mean } \\
\text { Score }\end{array}$ & $\begin{array}{l}\text { Standard } \\
\text { Deviatio } \\
\mathbf{n}\end{array}$ & Level \\
\hline 1 & $\begin{array}{l}\text { Problem-solving } \\
\text { and analytic }\end{array}$ & 3.38 & 0.87 & Moderate \\
\hline 2 & Time management & 3.39 & 0.83 & Moderate \\
\hline 3 & $\begin{array}{l}\text { Creativity, and } \\
\text { innovation } \\
\text { change }\end{array}$ & 3.19 & 0.83 & Moderate \\
\hline 4 & Learning & 3.35 & 0.75 & Moderate \\
\hline 5 & Personal strength & 3.25 & 0.77 & Moderate \\
\hline
\end{tabular}

\section{Perceived Importance versus Perceived Competence}

Figure 1 compares and ranks the students' perceived level of importance and level of competence by mean scores. As shown in the figure, time management skill came top of the list for both importance and competence level. This result is also similar for problem-solving and analytic skills, and learning skill. However, the ranks for creativity, innovation and change skill, and personal strength skill were opposite to each other. This means that although the students perceived creativity, innovation and change skills as important, they also believed that they are less competent in this skill as compared to other skills.

\section{DISCUSSION}

\section{A. Perceived Importance}

The high mean score results for the level of importance signify that the students are well aware of the importance of these skills for employability. Nevertheless, it is interesting to note that the students considered time management skill as the most important skill than problem-solving and analytic skill. Past studies, however, tend to highlight the latter as one of the important employability skills [see 13, 20]. In fact, according to Aziz [2], Malaysian graduates are lacking critical thinking skill which impede them from getting hired. Except in one study by Ahmad and Yahya [1], the authors indicated that one of the four characteristics that employers are looking for is punctuality. This corroborates with the students' perception of time management. Despite a small difference in the mean score, the result also appears to suggest that personal strength was perceived as the least important skill among other skills. Despite this, it is important to note that personal strength characters are in fact important in order to be employable [19]. Furthermore, Harvey [5] also indicated that personal strength is an important skill in job seeking.

\section{Fig. 1.Perceived Importance versus Perceived Competence}

\section{B. Perceived Competence}

The moderate mean score results for the level of competence suggest that the students are lacking in terms of competency in all the five dimensions of employability. The lack of creativity and critical thinking skills among Malaysian graduates are consistent with the findings from Majlis Penasihat Ekonomi Negara [10] and Aziz [2]. Interestingly, although this study appears to suggest that the students are moderately competent in problem-solving and analytic skill, Ismail ${ }^{7}$ argued that there is a huge gap between employers' expectations and graduates' performance for analytical and problem-solving skills. A similar result was also reported in an employability study towards technical and vocational students in Malaysia. In specific, Kazilan et al. [8] found that the students' employability skills are also at a moderate level.

\section{CONCLUSION}

In summary, this study has highlighted several key findings which require serious attention from the university. In particular, this study has revealed a mismatch between perceived importance and perceived competence of all the five dimensions of employability skills - problem-solving and analytic skills, time management skill, creativity, innovation, and change skill, learning skill, and personal strength among undergraduate university students in a Malayian public university. Although the students are highly aware of the importance of all the skills, the results show that their level of competence is at a moderate level. Hence several actions can be taken by the university to improve the students' competency level and increase their chances of getting hired. Through our survey, we also found that 50 percent of the students have attended several employability related programmes conducted by the university.

\section{Published By: \\ Blue Eyes Intelligence Engineering}


Nevertheless, as the result of this study suggests, those programmes appear to be inadequate, perhaps because the programmes are not tailored to the actual needs and skills gaps among the students. Hence it is suggested that the university plays a better role by ensuring that first, the needs of the students are properly identified, and second, to embed these skills into the curriculum and/or to develop and conduct additional skills enhancement programmes which are aligned with the needs of the students and the requirements of the industry. The findings of this study, however, are limited to third-year undergraduate students in one faculty in a public university in Malaysia. Thus the results are not generalizable as different universities may conduct various other employability related programmes which may yield different results.

\section{REFERENCES}

1. Ahmad, RM., and Yahya, B. (2011). Elements of employability skills among students from community colleges Malaysia. Journal of Technical, Vocational \& Engineering Education. 4, 1-11.

2. Aziz, H. (2018, October 3). Graduate skills gap. New Straits Times, Retrieved

from https://www.nst.com.my/education/2018/10/417327/graduate-skills-ga $\mathrm{p}$

3. Casner, J. (2006). Are they really ready to work? Employer's perspectives on the basic knowledge and applied skills of new entrants to the 21st century. Paper presented at: The Conference Board. New York.

4. Coll, R. and Zegwaard, K. (2006). Perceptions of desirable graduate competencies for science and technology new graduates. Research in Science \& Technological Education. 24(1), 29-58.

5. Harvey, L. (2015). Embedding and integrating employability. New Directions for Institutional Research. 128, 13-28.

6. Hawkridge, D. (2005). Enhancing students" employability: The national scene in business, management and accountancy. The International Journal of Management Education.

7. Ismail, MH. (2012). Kajian mengenai kebolehpasaran siswazah di Malaysia: Tinjauan dari perspektif majikan. Transformasi Ekonomi ke Arah Negara Maju: Prosiding Persidangan Kebangsaan Ekonomi Malaysia (PERKEM) VII. 2, 906-913.

8. Kazilan, F., Hamzah, R. and Rahim, B. (2009). Employability skills among the students of Technical and Vocational Training Centres in Malaysia. European Journal of Social Sciences. 9(1), 147-160.

9. Krejcie, R.V. and Morgan, D.W. (1970). Determining sample size for research activities. Educational and Psychological Measurement. 30, 607-610.

10. Majlis Penasihat Ekonomi Negara (MPEN). (2010). Model baru ekonomi untuk Malaysia. Putrajaya.

11. Northouse, P.G. Introduction to leadership: Concepts and practice. USA: Sage Publications, 2017.

12. Overtoom, C. (2000). Employability Skills: An Update. ERIC Digest No. 220. Retrieved from ERIC database (ED445236).

13. Paranto, S. R. and Kelkar, M. (2009). Employer satisfaction with job skills of business college graduates and its impact on hiring behavior. Journal of Marketing for Higher Education. 9(3), 73-89.

14. Rateau, R.J. (2011). Understanding the employability of college graduates for success in the workplace. Virginia Polytechnic Institute and State University, Blacksburg, United States.

15. Robinson, J., Garton, B. and Vaughn, P. (2007). Becoming employable: A look at graduates ${ }^{\text {ee }}$ and supervisorse perceptions of the skills needed for employability. NACTA Journal. 51(2), 19-26.

16. Sachs, J., Rowe, A. and Wilson, M. (2017). Good practice report Work Integrated Learning (WIL). Australian Government: Department of Education and Training.

17. Sahbulah, D. (2012, April 18). UUM Jana Kemahiran Insaniah. Utusan Malaysia, Retrieved from https://edisi-semasa.blogspot.com/2012/04/utusan-online-utara_18.ht $\underline{\mathrm{ml} \# 1}$

18. Sani, R. (2016, December 22). Seriously? Fresh grads asking for RM3k to 6k salaries, says survey. New Straits Times, Retrieved from https://www.nst.com.my/news/2016/12/198756/seriously-fresh-grads-a sking-rm3k-6k-salaries-says-survey
19. Shafie, A.L. and. Surina, N. (2010). Employability awareness among Malaysian undergraduates. International Journal of Business and Management. 5(8), 119-123.

20. Sibley, J. and Parmelee, DX. (2008). Knowledge is no longer enough: Enhancing professional education with team-based learning. New Directions for Teaching and Learning. 116, 41-53.

21. Sleap, M. and Reed, H. (2006). Views of sport science graduates regarding work skills developed at university. Teaching in Higher Education. 11(1), 47-61.

22. Yahya, B. (2014). Kemahiran "employability" (soft skills) dan kepentingan penerapannya di kolej-kolej kediaman pelajar. Malaysia Dokumen. Retrieved from https://vdokumen.net/kemahiran-employability-soft-skills-dan-kepenti ngan-.html

23. Yorke, M. (2010). Employability: Aligning the message, the medium and academic values. Journal of Teaching \& Learning for Graduate Employability. 1(1), 2-12.

\section{AUTHORS PROFILE}

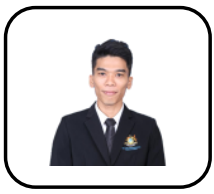

Bahru, Malaysia.
Mohamad Arsyhad received a Diploma in Management Technology in 2015. He then completed his Bachelor Degree in Human Resource Development in 2019.This article was based on his research for final year project at Faculty of Social Sciences and Humanities at Universiti Teknologi Malaysia, Johor

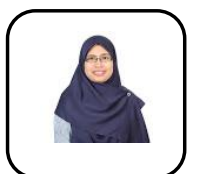

Rabeatul Husna Abdull Rahman is a senior lecturer at the Faculty of Social Science and Humanities, Universiti Teknologi Malaysia Johor Bahru, Malaysia. She received her PhD from University of South Wales Australia in 2013. Her research interest includes hurman resource management, human resource development, career studies, and labour force studies (youth, fresh graduate, talent/knowledge worker, disabled, female, aging and other special target groups)

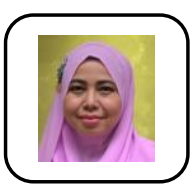

Salwa Abdul Patah is a senior lecturer at the Faculty of Social Sciences and Humanities, Universiti Teknologi Malaysia, Johor Bahru, Malaysia. She received her PhD from the University of Western Australia in 2017. Her area of research includes training and development, human resource management, performance management, leadership and organizational behavior

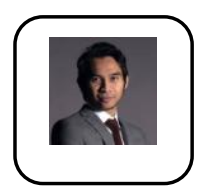

Wan Mohd Azam Wan Mohd Yunus is a senior lecturer in psychology at the School of Human Resource Development \& Psychology, Faculty of Social Sciences and Humanities, Universiti Technology Malaysia. He obtained his Ph.D in Clinical Psychology at King's College London, UK and M.Clin.Psych at Universiti Kebangsaan Malaysia. He is currently active in research related to digital mental health, clinical psychology and abnormal psychology.

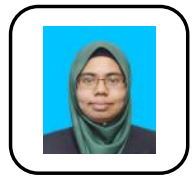

Nurul Labanihuda Bt Abdull Rahman has a Diploma in Accountancy and a Bachelor Degree in Islamic Banking from MARA Universiti of Techology (UiTM) in 2009 and 2012. She then pursued her Master's degree in Islamic Finance and Banking in Universiti Utara Malaysia (UUM) and graduated in 2014. Following that she continued with her doctoral studies in Business Information System from the same university and graduated last year. She is actively involved in teaching, research and publication. Currently she works as a lecturer at the Department of Finance, Faculty of Business Management, MARA Universiti of Techology (UiTM). Her current research interest includes Business Management studies, Islamic Banking, Finance studies and Islamic economic studies

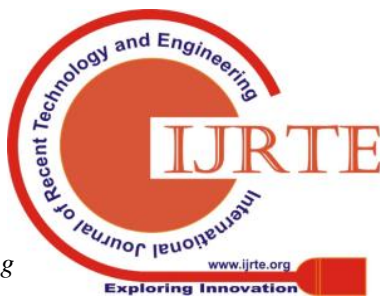

